Religare, ISSN: 19826605, v.15, n.1, agosto de 2018, p.260-286.

\title{
A Espiritualidade para além ao Mito a da Religião Institucionalizada
}

\author{
Spirituality Beyond The Myth And Religion
}

Carlos Alberto Tolovi ${ }^{1}$

\section{Resumo}

Podemos dizer que, de certa maneira, todo ser humano busca uma forma de transcendência. Em determinados momentos a realidade "nua e crua" da imanência pode nos parece demasiadamente dura ou muito limitada. Porém, como somos dotados do recurso natural da imaginação, buscamos transcender os limites do nosso "mundo" empírico exercitando a nossa liberdade de transcender. Sendo assim, na busca de transcendência buscamos também superar o caráter infindável de luta do espírito em constante incompletude, tendo de enfrentar permanentemente as incertezas da contingência. E para superar essa fragilidade ou angústia da existência o ser humano busca a totalidade. É neste contexto que são criados os dogmas, os mitos e as instituições religiosas, tendo em vista a definição de um "lugar" onde o espírito possa repousar. Contudo, estas formas de totalidade não estariam justamente oferecendo um outro limite para a transcendência? Se a transcendência significa uma das formas de manifestação da liberdade humana, a institucionalização da mesma não significaria uma forma de limitá-la? Estas provocações sinalizam o propósito do nosso trabalho: refletir sobre o mito e a religião nos limites da natureza humana, tendo como desafio a possibilidade de transcendência pela espiritualidade. Neste sentido, apontamos uma hipótese: sempre que o ser humano buscar descrever e definir o mistério, objetivando-o como sagrado, estará produzindo um mito que limita a espiritualidade. Por outro lado, negar a objetivação ou institucionalização da divindade não significa negar a existência do divino. $\mathrm{E}$ esta abertura ao mistério, sem as amarras dogmáticas e doutrinárias, consiste na característica de uma nova espiritualidade que pode ser compreendida dentro do campo da mística. Neste campo, o grande desafio consiste na aceitação do "mistério" sem, no entanto, a necessidade de aprisioná-lo ou caracterizá-lo.

\footnotetext{
${ }^{1}$ Graduado em Filosofia. Mestrado e doutorado em Ciência da Religião pela PUC - SP. Professor efetivo do Departamento de Ciência Sociais da Universidade Regional do Cariri - Filosofia.
} 
Palavras-Chave: Espiritualidade; Mito; Religião

\section{Abstract}

We can say that, in a way, all human beings search for a kind of transcendence. Sometimes the reality of immanence can seem too hard and too limited. However, as we can naturally appeal to our imagination, we try to overcome the limits of our empirical world by exercising our capacity of transcendence. So, in the search for transcending, we also try to overcome the endless struggle of the spirit in its incomplete structure, permanently facing the incertitude of our limitation. In order to overcome this fragility or the existential anguish, man searches for holiness. In this context, dogma, myth and religious institutions are created in order to define a "place" where the spirit can rest. However, we ask if these kinds of totality would not be offering just another limit for transcendence. If transcendence is a manifestation of human freedom, wouldn't it limit human freedom when institutionalized? These questions indicate the purpose of our research: the reflection on myth and religion in the borders of human nature, having as a challenge the possibility of transcending by spirituality. We point out this hypothesis: whenever the human being tries to describe and define mystery as an objectified sacred, he will be creating a myth that imposes limits to spirituality. On the other hand, accepting the divinity inside an institution does not mean denying it. This openness to the mystery, without dogmatic ties, is the characteristic of a new spirituality that can be understood within the mystic field. The challenge is to accept the mystery without imprisoning it inside definitions.

Keywords: Spirituality; myth; Religion

\section{Introdução}

Compreendemos que filosofia e religião, apesar de possuírem campos específicos, possuem também conexões irrefutáveis. “Quem quiser tirar a religião de um projeto tão abrangente quanto a filosofia vai descobrir que uma grande parte do ser humano, do mundo e da experiência em geral vai sumir junto" (PAINE, 2013, p.111). O tema do mito é um exemplo disso. A ciência da Religião reconhece essa conexão e busca extrapolar os limites 
dogmáticos e doutrinários que almejam isolar determinados temas como sendo "elemento de fé".

No caso do mito, o diálogo com a filosofia torna-se indispensável. Principalmente pelo seu caráter antropológico. Isto é, pela sua relação direta, imediata, indistinta e inseparável da existência humana. Mas também pelo fato de assumir como ponto de partida um problema fenomenológico. Afinal, se tomarmos a ideia de fenômeno como a manifestação de algo, como podemos definir aquilo que se manifesta? É o sagrado que produz a experiência religiosa, ou é o ser humano, através de suas experiências pessoais, culturais e psicológicas, no uso de sua imaginação, que exercita a sua capacidade de sacralização?

Buscando responder esta questão partiremos da concepção de que mito e religião nascem de um mesmo "lugar": desejo e necessidade da coletividade. Possuem também as mesmas funções: explicar, justificar, ordenar a "realidade", acomodando os seres humanos dentro da mesma. No âmbito destas necessidades, os deuses mitológicos são criados por meio das narrativas, tornando-se expressões dos desejos e das necessidades coletivas. Desta forma, entendemos que é justamente através do mito e da religião que mais podemos compreender os seres humanos vivendo socialmente. Mesmo porque só é possível conhecer um determinado grupo social a partir de suas formas de manifestações coletivas. Como afirma Cassirer, "no pensamento e imaginação míticos não encontramos confissões individuais" (CASSIRER, 1976, p.63).

Diante do exposto, partiremos da ideia de que o ser humano é um ser em construção. Precisa construir uma ordem no "caos", transformando a natureza e partilhando símbolos e signos (e assim produz cultura); precisa construir uma ordem de sentido, partilhada intersubjetivamente e coletivamente (e assim produz sociedade); por fim, precisa construir mediações que facilitem a relação dialética entre a objetividade do mundo e um mundo subjetivo.

Neste contexto definido, tomaremos o mito na perspectiva de um instrumento de mediação entre a objetividade e a subjetividade humana, 
possibilitando a explicação e justificação de uma determinada "realidade" mediante uma narrativa. $\mathrm{O}$ mito faz parte desse processo de construção e mantém a sua estrutura, mesmo se adaptando às mais diversas necessidades da coletividade com o passar do tempo.

É nesta mesma perspectiva que trabalhamos com o conceito de religião. Não como essência, mas como consequência da "natureza humana", que sente a necessidade de transcendência e que a produz a partir dos limites da imanência. No caso do mito, essa projeção é sempre coletiva. Portanto, não estaremos colocando em questão a existência de Deus ou a veracidade da fé. Estaremos situados nos limites da dimensão antropológica, buscando separar a objetivação do sagrado (mito) da manifestação do divino (apofático, indefinível). Isto é, no papel de pesquisador da Ciência da Religião, estando fora do mito, não seria coerente toma-lo como um "Deus verdadeiro". Por outro lado, não temos a pretensão de desvendar o mistério onde, para nós, estaria o "lugar" do divino e da mística. O que nos força a admitir que "a realidade última é inacessível ao entendimento humano, inexpressível pela linguagem humana, invisível aos olhos humanos" (BULHOF, 2000, p.6). O problema é que, na nossa cultura ocidental, não conseguimos criar nossos ritos, partilhar nossa fé coletivamente, sem que o mistério "ganhe forma" visível, palpável, localizado e objetivado. E o mito está nos limites desta formatação especificamente humana. Situado nos limites da linguagem e da condição humana. Onde, como afirma Tillich,

A mente recebe e reage. Ao receber racionalmente, a mente compreende o seu mundo. Ao reagir racionalmente, a mente estrutura o seu mundo. "Compreender" neste contexto tem a conotação de penetrar na profundidade, na natureza essencial de uma coisa ou evento, de entendê-lo e expressá-lo. "Estruturar" neste contexto tem a conotação de transformar o material dado numa Gestalt, numa estrutura viva que tem o poder de ser (TILLICH, 1987, p.71). 
Neste mesmo campo do idealismo podemos invocar também Feuerbach, colocando Deus como a essência humana exteriorizada. O ser humano, não reconhecendo a sua essência projetada, a toma como uma realidade divinizada. ${ }^{2}$

Neste sentido, situando a teologia nos limites da antropologia, Feuerbach situa o ser humano nos limites da realidade corporal e da sensibilidade. Enfim, ele situa a divindade nos limites da natureza humana. A partir desta concepção está definida a principal característica de mito. $\mathrm{O}$ ser humano possui a capacidade de divinizar aquilo que ele mesmo projeta por meio de sua imaginação, provocada por seus desejos e suas necessidades. Além do mais, ele possui também a capacidade de transferir para o ser projetado aquilo que deveria assumir como responsabilidade sua. $\quad \mathrm{E}$ isso é feito por meio da divinização da projeção. Sempre contando com a narrativa simbólica como o seu principal "instrumento" de construção. Sendo assim, quando a palavra humana é transformada em "palavra divina", a ação do ser humano está justificada. Tanto para o bem quanto para o mal. Tanto as boas, quanto as más ações. Mesmo porque, nos limites da cultura, está a moral. E nos limites da moral estão os valores que definem o bem e o mal. O que, por sua vez, até certo ponto, relativiza a questão. Neste sentido, aquilo que era apenas fruto da imaginação, passa a interferir diretamente na realidade concreta. A concepção religiosa se transforma em valores morais e sociais. Estes valores determinam a ideia de bem e de mal, de certo e errado, de justo e injusto. Por sua vez, estes mesmos valores conduzem o ser humano a uma forma de organização social. É neste contexto de concretude que estaremos situando mito e religião. A imaginação pode levar à objetivação da divindade. É nesta objetivação que se localiza o mito. Contudo, a religião se localiza no

\footnotetext{
2 Sobre este assunto Cfr. Ludwig Feuerbach. A Essência do Cristianismo. 2ª . ed. Campinas: Ed.
} Papirus, 1997 (Trad. José da Silva Brandão) 
processo de ação e materialização do que foi imaginado e transformado em um conjunto de signos e símbolos. E aqui se localiza a "veracidade" da religião, (principalmente nos limites da cultura ocidental) isto é, na realidade concreta do ser humano vivendo em sociedade. A religião, vivenciada através dos ritos, define valores morais que, por sua vez, determinam a relação intersubjetiva.

Porém, a grande questão que colocamos aqui consiste no desafio de pensar a espiritualidade para além do mito e da religião. Enfim, para além das instituições religiosas.

\section{Mito e Religião como forma de Institucionalização da Fé}

Mas, como entender o lugar do mito nesse processo?

Os mitos são construídos com o "barro da cultura". Assim, eles assumem a masculinidade ou a feminilidade, assumem uma determinada moral, assumem determinadas exigências no campo do comportamento humano-coletivo.

Portanto, retomando novamente o conceito de Feuerbach (projeção humana) e recorrendo ao conceito de imaginação, podemos afirmar que a religião é fruto da expressão e projeção da essência humana. Ela mesma - a religião - não é projeção, mas manifestação concreta dos seres humanos diante do que estes consideram como sagrado. Sendo assim, o conceito de essência humana não se refere à um ser imutável, mas a características próprias e definidoras do ser humano, no sentido de sua espécie, de sua natureza. Portanto, se de um lado a religião é fruto da imaginação e mediação para a transcendência, de outro, ela está situada no campo concreto da imanência.

No entanto, como definir esse conceito de imaginação e de que forma ele está presente na dimensão do mito e da religião? 
Para respondermos esta questão recorremos à Gilbet Durand:

$\mathrm{O}$ mundo em que as ideias, as formas puras espirituais do platonismo se corporalizam, e, consequentemente, adquirem uma forma simbólica, tomando "corpo" e podem, por isso mesmo, polarizar o desejo, em que reciprocamente os corpos, quer dizer, os objetos do mundo sensível, se espiritualizam, ou seja, ascendem ao sentido e, consequentemente, prolongam o desejo até ao seu horizonte semântico e escatológico (DURAND, 1979, p.34).

Como podemos perceber, Durand coloca a imaginação como uma dimensão humana que possibilita transcender para além da imanência. $\mathrm{Na}$ imaginação os desejos humanos ganham forma e podem ser divinizados.

É por ela (pela imaginação) que passa a doação do sentido e que funciona o processo de simbolização, é por ela que o pensamento do homem se desaliena dos objetos que a divertem, como os sonhos e os delírios que a pervertem e as engolem nos desejos tomados por realidade (DURAND, 1984, p.37).

Por conseguinte, por meio da imaginação o ser humano possui a possibilidade de projetar imagens que, por sua vez, possibilitam responder aos questionamentos e as necessidades básicas da consciência existencial. Que ainda não é uma consciência filosófica ou científica, pois não depende da fundamentação racional. Refere-se à percepção de ser e estar no mundo e em relação ao mundo. Neste sentido, só é possível tomar consciência da existência de algo se antes já tomei consciência de minha própria existência, que seria a percepção da própria consciência.

Sendo assim, a minha consciência existencial me transforma no sujeito de minha experiência. Por outro lado, ela possibilita ao ser humano sair de si mesmo. Entrar na imbricada e complexa realidade do Ser em si e do Ser para $\mathrm{si}^{3}$. Isso, no entanto, leva o sujeito à percepção da liberdade que, por sua vez,

\footnotetext{
${ }^{3}$ Abordando este tema Merleau Ponty afirma que "existem dois e somente dois modos de ser: o ser em si, que é aquele dos objetos estendidos no espaço, e o ser para si, que é aquele da consciência". Cfr. M. Merleau Ponty. Fenomenologia da Percepção, São Paulo: $4^{\mathrm{a}}$ ed. Ed. Martins Fontes, 2011, p.468. (Trad. Carlos Alberto Ribeiro de Moura).
} 
o coloca no campo da responsabilidade. O que, para o ser humano, se transforma em um de seus maiores desafios existenciais.

Neste campo de reflexão não podemos deixar de evocar Heidegger referindose à angústia.

A angústia arrasta o Dasein para o ser-livre, [...] para a propriedade de seu ser enquanto possibilidade de ser aquilo que já sempre é. O Dasein como ser-no-mundo entrega-se, ao mesmo tempo, à responsabilidade desse ser (HEIDEGGER, 1988, p. 250).

No entanto, uma das funções do mito é possibilitar ao ser humano a fuga ou negação desta responsabilidade para sentir-se mais seguro e tranquilo, com um "fardo mais leve". Essa é uma das características do mito. Neste sentido Deus e o Diabo aparecem com a função de "expropriação da consciência". A expressão "vontade de Deus", ou "ação do Diabo" reflete muito bem este contexto. Dessa forma o ser humano interpreta como ação divina ou diabólica aquilo que deveria ser visto como consequência de suas escolhas ou como responsabilidade sua. E isso se dá no nível do senso comum ${ }^{4}$, onde uma visão de mundo assumida coletivamente, sem fundamentação racional, se transforma em justificativa para a ação individual. O que não elimina todos os questionamentos. Mas oferece uma referência segura para uma adesão coletiva.

Neste mesmo contexto é possível compreender outra afirmação de Heidegger, que coloca a consciência da existência antes do desconhecido e como base para este. “O desconhecido não é aquilo a respeito do qual não sabemos absolutamente nada, mas é aquilo que, no que conhecemos, se impõe a nós como elemento de inquietação" (HEIDEGGER, 1986, p.217). Sendo

\footnotetext{
${ }^{4}$ A partir de uma perspectiva filosófica o senso comum é um conhecimento que não exige reflexão ou fundamentação; um conhecimento adquirido geralmente a partir das vivências e experiências acumuladas e repassadas culturalmente. O que significa dizer que há conhecimento no senso comum, e o mesmo deve ser respeitado. Contudo, no campo acadêmico e científico, esse conhecimento pode servir apenas como "ponth de pàrtida", não como "ponto de chegada".
} 
assim, quando algo se manifesta, se manifesta sempre para a consciência. $\mathrm{O}$ que não quer dizer que este algo não exista fora da mesma. Contudo, essa manifestação dá origem ao que nós definimos como desconhecido. O que ocorre no momento em que nós percebemos a "existência de". Neste caso, o desconhecido é posterior à tomada de consciência da existência de algo e da existência da própria consciência. Nesta perspectiva podemos acolher uma afirmação de Marcelo Perine: “A raiz do humano está na consciência” (2007, p.57).

Neste sentido, podemos nos questionar sobre a "revelação". O que nos remete novamente ao campo da fenomenologia. E que, por sua vez, nos faz lembrar também de Husserl. Isso porque, tanto em Heidegger quanto em Husserl “encontramos a mesma intenção dominante de garantir o alcance do transcendental" (BEAUFRET, 1976, p.43). O que representa uma grande diferença no que se refere a tentativa de compreender o transcendente. $\mathrm{O}$ transcendental estaria nos limites da ação da consciência humana. Aquilo que é captado e organizado por ela. Diferentemente do transcendente - aquilo que está "fora" destes limites. Sendo assim, Husserl, em um primeiro momento ${ }^{5}$, afirma que "a tarefa da fenomenologia é, pois, estudar a significação das vivências da consciência. [...] Descrever a estrutura do fenômeno como fluxo imanente de vivências que constitui a consciência (estrutura constituinte)" (HUSSERL, 1996, p.18-19). Portanto, a essência não estaria na "coisa em si", mas na consciência. Sendo assim, podemos refletir melhor sobre a afirmação de Feuerbach, colocando Deus como uma essência humana exteriorizada. Exteriorização que parte de uma necessidade. Necessidade que não é apenas de um indivíduo isolado, mas de uma determinada coletividade, inserida e

\footnotetext{
${ }^{5}$ Em uma segunda fase Husserl apresenta maior preocupação com as evidências pre-lógicas e com o mundo dos valores, diante da crise da humanidade, da civilização. Cfr. Edmund Husserl. A crise da humanidade europeia e a filosofia. $3^{\underline{a}}$ ed. Porto Alegre: Edipucrs, 1996. (Introdução e Trad. Urbano Zilles). 
desafiada por uma determinada realidade concreta. Neste sentido, a imaginação é o que possibilita a projeção.

Segundo Gilbert Durand (1964), a consciência humana dispõe de duas formas básicas de apreensão da realidade. Uma forma direta na qual a realidade emerge ao espírito como uma percepção ou uma simples sensação. E, outra forma, indireta, na qual a realidade não pode se apresentar imediatamente à sensibilidade, e é então representada por uma imagem (AMORIM, 2009, p.1).

E aqui novamente podemos fazer uma ponte entre a antropologia de Feuerbach e a fenomenologia de Husserl. Pois, para este, a consciência é sempre consciência de algo, que se traduz como "intencionalidade". Portanto, no campo do mito e da religião podemos dizer que o mistério é a "coisa" - o desconhecido - captada pela consciência, reelaborada por ela e que passa a ser uma "fonte de sentido". Como afirma Croatto, "O encontro com o mistério afeta profundamente o ser humano" (CROATTO, 2010, p.65).

Mas, como definir este mistério? Seria a manifestação de algo que a consciência ainda não havia captado e que, ao captar, o percebe como desconhecido. "Coisa secreta" - Mystérion. Algo velado. O que estaria "escondido". É nesse sentido que
A palavra 'revelação' (remover o véu) foi usada tradicionalmente para significar a manifestação de algo escondido que não pode ser alcançado através das formas ordinárias de conseguir conhecimento. [...] Esse ocultamento é frequentemente chamado de 'mistério'. [...] Em sentido próprio, é derivado de muein, 'fechar os olhos', ou 'fechar a boca' (TILLICH, 1987, p.96-97).

Diante do mistério o ser humano pode assumir dois posicionamentos ou atitudes que denominamos como "clássicas": tentar descrevê-lo pela imaginação, formalizada por uma narrativa simbólica, em busca de sentido; ou aceitar os limites da razão, sem neutralizar a sua ação. Esta segunda atitude é a que pode levar o "crente" ao universo da mística. 
É aqui que localizamos o divino "não mitologizado", não objetivado, não descrito e caracterizado pela imaginação. "O mistério caracteriza uma dimensão que 'precede' a relação sujeito-objeto" (TILLICH, 1987, p.97). É neste sentido que Martin Buber afirma: "Não é necessário que se saiba algo sobre Deus para realmente pensar em Deus, e muitos fiéis verdadeiros sabem falar a Deus, mas não sabem falar de Deus" (BUBER, 2007, p. 28). O que deixa claro que a fé não depende dos limites da racionalização teológica.

Podemos afirmar que a religião e o mito estão intimamente ligados ao universo sobrenatural e misterioso. Aliás, é uma forma de resposta provocada pelo desconhecido. Como afirma Durkheim,

Uma noção que geralmente é considerada como característica de tudo aquilo que é religioso é a de sobrenatural. Com esse termo entende-se toda ordem de coisas que vai além do alcance do nosso entendimento; o sobrenatural é o mundo do mistério, do incognoscível, do incompreensível (DURKHEIM, 2008, p.54).

Mesmo assim, a consciência capta o desconhecido como uma "coisa" que exige explicação, justificativa, para evitar o caos. Neste contexto, aquilo que a imaginação produz e projeta por meio de uma narrativa para a coletividade, ganha "corpo", materializando-se nos signos, passando a ser visto como "totalmente outro", representado pelo símbolo. O que, no campo da filosofia marxista, poderia ser tomado como uma forma de alienação. Aquilo que o ser humano produz e depois não reconhece mais como sua própria produção. Uma "realidade" criada pelo próprio ser humano, mas vista como se existisse independentemente dele ou completamente fora dele. E o pior: aquilo que é produzido parece ganhar vida independente e se torna maior do que o seu produtor, dominando a sua cosmovisão e o seu comportamento. Uma forma de fetichismo.

Por outro lado, aquilo que é captado pela consciência e projetado pela imaginação passa a oferecer um "universo de sentido". Como afirma Croatto, 
“Todo mito é delimitador de uma cosmovisão. [...] O mito, de fato, é instaurador de realidades significativas" (CROATTO, 2010, p.272). Portanto, o que a narrativa mítica produz já se localiza na concretude histórica da vida humana e se torna determinante para a organização social. Ela passa a fazer parte do nível da "consciência empírica", uma consciência coletiva ligada diretamente à realidade vivencial, que passa pela intersubjetividade, define uma determinada visão de mundo e se torna real na concretude prática da vida em sociedade. Neste sentido,

O nível empírico da consciência se define pela presença do sujeito ao aqui e agora da sua experiência sensível e emocional. A consciência mítica, forma do existir para si do ser humano no nível empírico, é a forma originária da presença do ser humano no mundo e o ponto de partida de sua afirmação como sujeito. [...] A consciência mítica é a primeira forma de conhecimento que o ser humano tem de si, que já implica, embora de forma não percebida reflexivamente, uma separação do ser humano com relação ao seu mundo circundante (PERINE, 2007, p.79).

Em uma outra perspectiva, após a emergência da consciência empírica, que coloca o ser humano no mundo e distinto do mesmo, podemos dizer que a consciência passa a ser delimitada pela "intencionalidade", que, por sua vez, está ligada diretamente a necessidade de sujeitos históricos inseridos em seu mundo concreto, por meio de seu corpo, que lhe possibilita a percepção. Neste sentido podemos nos remeter à Merleau Ponty, colocando o corpo como o lugar e a fonte da percepção, buscando fugir das "trilhas" do idealismo. O corpo é a possibilidade da percepção e da existência. Ele está enraizado em uma determinada cultura, agindo e interagindo dentro da mesma. Portanto, vale a crítica de Marx direcionada à Feuerbach. A projeção do divino e a influência do projetado sobre a realidade humana não pode ser pensada de forma desconectada da realidade vivida, com todos os seus conflitos, na luta pela sobrevivência. Isso porque, como afirma Newton Duarte, 
Não existe uma essência humana independente da atividade histórica dos seres humanos, da mesma forma que a humanidade não está imediatamente dada nos indivíduos singulares. Trata-se de produzir nos indivíduos algo que já foi produzido historicamente (DUARTE, 2003, p.30).

Neste contexto, o estudo do mito ganha relevância a partir da busca pela compreensão do "mundo vivido". Um espaço onde se cruzam a "intencionalidade" e a "intersubjetividade". O "lugar" das necessidades.

Como afirma Merlaeu Ponty, "O sujeito que percebe deixa de ser um sujeito pensante 'acósmico'” (2006, p.50). Esta percepção se caracteriza como pré-reflexiva. Um "lugar" onde a ciência não alcança, pois está ligado a uma experiência vivencial, dentro do mundo vivido, não do mundo evidenciado racionalmente. Este é o "lugar" do mito. O que não quer dizer que ele não possa ser narrado ou construído pela ciência. A ciência também produz seus mitos. Contudo, também o mito científico exige aceitação coletiva (fé), ritual e a definição de algo como "sagrado" e infalível.

Uma outra questão que deve ser destacada é o fato de que, simbolicamente, o mito não nasce da razão filosófica, teológica ou científica, mas do "coração". O que nos remete à uma celebre afirmação provocativa de Pascal, dizendo que o coração tem razões que a própria razão desconhece. É por isso também que Augusto Novaski afirma que "o ser humano é colocado no ser não pela razão ou pelo intelecto, mas pelo desejo" (NOVASKI, 1988, p.26).

Por outro lado, podemos dizer que "não é possível descrever o mito como simples emoção, porque constitui a expressão de uma emoção; a expressão de um sentimento não é o sentimento mesmo, é uma emoção convertida em imagem" (CASSIRER, 1976, p.189).

A partir destes elementos podemos elaborar melhor a nossa compreensão sobre o mito, fazendo uma trajetória de trás para frente, 
reconhecendo a contribuição e os limites de cada pensador citado por nós, a partir de uma perspectiva dialética.

Se mito corresponde a uma projeção dos desejos e necessidades da coletividade, esta projeção, por sua vez, se dá pela imaginação. Mas, a imaginação que projeta depende da percepção. No entanto, a percepção depende do corpo. Por fim, podemos dizer que este corpo representa o lugar da síntese entre o existir e o pensar, entre o ser que busca se autocompreender e o poder ser que busca se projetar. E a sua auto-compreensão se dá por meio da cultura.

\subsection{A Cultura como substrato do Mito e da Religião}

Mas, afinal, qual é o conceito de cultura que define a perspectiva apresentada anteriormente?

No contexto do mito, em uma perspectiva antropológica, o autor que mais colabora para explicitarmos o conceito de cultura é Clifford Geertz.

Mesmo porque este entende cultura como uma teia de significado, construída por meio de símbolos e signos compartilhados. ${ }^{6}$ E se nós estamos defendendo o estudo do mito através do conhecimento da natureza humana, Geertz pode dar a sua contribuição. Para este autor, toda cultura possui uma ideologia que serve como base para o senso comum. Mesmo porque a cultura é elaborada e mantida por meio de uma teia complexa de signos, os quais produzem e projetam significados que orientam a ação coletiva, produzindo uma forma de ideação, que consiste em ideias que perpassam a intersubjetividade de um determinado grupo social e se transformam em ações concretas. Em sua obra A Interpretação das Culturas Geertz se empenha em compreender e explicitar a dimensão significativa da cultura. O que se

\footnotetext{
${ }^{6}$ Sobre este assunto Cfr. Clifford Geertz. A Interpretação das culturas. Rio de Janeiro: Ed. Zahar, 2004.
} 
aproxima muito do objetivo deste nosso trabalho: entender o mito na perspectiva da busca de sentido e da natureza humana.

O conceito de cultura que eu defendo é essencialmente semiótico. Acreditando, como Max Weber, que o homem é um animal amarrado à teias de significado que ele mesmo teceu, assumo a cultura como sendo estas teias e sua análise, portanto, não como uma ciência experimental em busca de leis, mas como uma ciência interpretativa, à procura do significado (GEERTZ, 1984, p.15).

Apesar deste conceito não esconder os seus limites epistemológicos, dentro do recorte que estamos fazendo, na perspectiva do mito, ele nos oferece uma preciosa contribuição. Mesmo porque é nesta perspectiva de "teia de significados", elaborada por meio de signos e símbolos, que colocamos o conceito de imaginação. Uma forma de projeção de imagens que produzem e projetam significados que extrapolam os limites dos objetos imanentes, produzindo uma "realidade" transcendente, com impacto direto na concreta realidade social. A questão é saber se são os processos sócioestruturais que servem de substrato à produção dos símbolos religiosos ou se são estes símbolos que moldam a estrutura. No nosso caso, escolhemos pensar essa questão não como colocando-a em compartimentos estanques, mas dentro de um processo dialético.

Por um lado, ao perpassar a intersubjetividade de um determinado grupo social, o conjunto de símbolos e signos se transforma em referencial concreto e determinante para a visão de mundo e o comportamento dos indivíduos vivendo socialmente. “O símbolo, portanto, é gerador de um vínculo entre os seres humanos. Por essa função, sua própria existência representa um ato social" (CROATTO, 2010, p.113).

O mito representa uma das formas de manifestação dos desejos de um determinado grupo social. Manifestação que só pode ser compreendida no "universo" da mundaneidade. Esta perspectiva extrapola os limites da "pura subjetividade". Mesmo porque, a projeção realizada por meio da imaginação 
está diretamente conectada a uma realidade concreta, que desafia a compreensão do ser humano e lhe impõe limites. Limites que "potencializam" a busca da transcendência, que envolve toda uma coletividade, inserida em uma mesma cultura. Como afirma Duarte,

A consciência e a vontade do indivíduo se formam a partir de sua inserção no mundo social, no mundo da cultura. A idealidade não está presente na natureza, seja ela natureza externa ao ser humano, seja a natureza corpórea do ser humano, assim também como não é produto de algum mundo das ideias existentes acima e independentemente da história social. Igualmente a idealidade não é um fenômeno subjetivo, individual, mas sim um produto objetivo da prática coletiva, uma resultante das relações sociais reais que estão presentes na atividade social. $O$ mundo da consciência individual é construído com base na apropriação dessa identidade existente nos fenômenos sociais (DUARTE, 2003, p.99).

E aqui entramos em uma questão fundamental. Onde estaria o fundamento da identidade do fenômeno religioso?

\section{O ser humano se relaciona com o Sagrado ou com o "Sacralizado"?}

Se tomarmos a ideia de que a idealidade é um produto humano, e afirmarmos que a religião é uma forma de idealidade cultural, teremos de concluir que a religião é uma construção social. Porém, a construção da religião tem como base a narrativa mítica. Neste contexto, mito e religião fazem parte dos fenômenos sociais que mais influenciam a visão de mundo, o comportamento e as relações humanas no campo da intersubjetividade.

Desta forma, nos deparamos novamente com o conceito de fenômeno. Neste campo, o mito e a religião possuem muita coisa em comum com relação ao ser humano: consciência da imanência, transcendência pela imaginação e 
pela linguagem simbólica, aceitação coletiva, sacrifícios e rituais. A diferença é que o mito não precisa de racionalização e nem de burocratização. Porém, não podemos deixar de destacar que no coração do mito e da religião está a "manifestação do sagrado". E de acordo com o que trabalhamos anteriormente, devemos retomar a questão central: o que é que se manifesta? É o sagrado que se manifesta ao ser humano? Ou é apenas o desconhecido que se manifesta para a consciência? Ou então, como pergunta Jacques Derrida: “[...] o acontecimento da revelação teria consistido em revelar a própria revelabilidade, e a origem da luz, a luz originária, a própria invisibilidade da visibilidade?" (2000, p.27). Nesse sentido, dar-se conta do desconhecido já não seria uma forma de conhecimento? Dar-se conta do "mistério" já não seria uma forma de revelação?

Enquanto para o "homo religiosus" o sagrado é algo que existe independente do ser humano, pela nossa teoria, ele não existe em si mesmo e é completamente dependente da existência humana e dos limites de sua cultura. Neste caso, o que existiria como objeto de fé não poderia ser definido como "sagrado", mas como "consagrado".

Para Husserl toda consciência é consciência de algo. Para nós, todo sagrado é uma forma de manifestação da própria consciência humana em relação a algo tomado como desconhecido. Portanto, o sagrado é posterior à consciência existencial. Sendo assim, algo só poderia ser tido como sagrado depois de ser sacralizado. E, para sacralizar, o ser humano precisaria projetar sobre este algo os seus "valores culturais". Por esta perspectiva, como cientista da religião, temos de afirmar que o sagrado não poderia ser pressuposto. Não existiria fora e nem para além da existência humana. Sendo assim, o sagrado seria uma forma de ideação que se materializa na objetivação, tendo o símbolo como forma de mediação.

Portanto, para o religioso afirmar a existência do sagrado independente da consciência e da cultura ele precisa recorrer à fé. É pela fé que o "homo 
religiosus" sacraliza um espaço, um objeto, um território.

Portanto, a

fé é justamente o instrumento humano de sacralização. Por outro lado, o "homem religioso", estando no "coração" do mito, pressupõe e vivencia o sagrado. Como o exemplo de Abraão diante da exigência do sacrifício de Isaac. Uma fé identificada por Kierkegaard como "paixão" - um "salto no escuro"7. Neste sentido, nos encontramos diante de dois fenômenos que desafiam o cientista da religião: a manifestação da fé do homo religiosus (situado no "coração" do mito) e a manifestação do "sagrado" para quem não toma a fé como pré-suposto (situado fora do mito). Diante do primeiro desafio, o cientista da religião toma as manifestações do Homem $^{8}$ religioso como fenômeno que deve ser compreendido a partir dos signos e símbolos. Diante do segundo, ele toma o mistério como fenômeno que desafia a compreensão humana a partir de uma perspectiva filosófico-antropológica. O que poderia ser identificado como um "deserto dentro do deserto". ${ }^{9}$ Neste caso, a manifestação de fé do "homo religiosus", a existência do divino, nada é tomado como falso, mas como um fenômeno situado nos limites da condição humana, podendo ser pensado pela razão. E, dentro destes limites a sacralização estará sempre relacionada a três dimensões fundamentais: a) a necessidade de objetivação da fé b) a intencionalidade c) a relação de poder.

Neste contexto, precisamos deixar bem clara uma distinção: a realidade, apesar de contingente, existe independente da nossa consciência. Mas esta realidade jamais pode se manifestar como sagrada - em si mesma para o ser humano. É por isso que toda religião é uma forma de ideação, porque depende do "universo humano" que corresponde à sua "valoração".

\footnotetext{
${ }^{7}$ Sobre este assunto Cfr. KIERKEGAARD, S. Temor e Tremor. Tradução de Maria José Marinho, Introdução de Alberto Ferreira. Lisboa: Guimarães Editores, 1990.

8 " $\mathrm{H}$ " - Uma forma de sinalizar a dimensão de gênero, buscando evitar a dimensão machista da linguagem.

${ }^{9}$ DERRIDA, J. Fé e Saber. As duas fontes da "religtão" nos limites da simples razão. In. VV.AA. A Religião. São Paulo: Ed. Estação Liberdade Ltda. 2000. Pg.28.
} 
Se os valores humanos são produções humanas e se o sagrado é constitutivamente um ato de valoração, então o sagrado é uma projeção humana que ganha corpo a partir dos seus valores.

Mas, como a sacralização se transforma em um fenômeno social?

Por meio da linguagem. A linguagem simbólica é a mediação necessária e indispensável para a socialização, a "materialização" e a objetivação do consagrado.

E aqui precisamos trazer uma questão fundamental: se o sagrado é uma forma de ideação, como explicar a concretude da religião e da fé na vida das pessoas e na sociedade?

Um conceito de Heidegger pode facilitar o nosso entendimento. Para Heidegger, o ser humano habita a linguagem e a linguagem habita o ser humano. Portanto, “a linguagem é a morada do ser" (HEIDEGGER, 2003, p.64). Sendo assim, se tomarmos a linguagem como o "lugar" da manifestação do sentido, podemos compreender o fato de a linguagem ser o "lugar" onde habita o divino. De uma forma ou de outra, está na linguagem a expressão dos limites da dimensão humana, representada muito bem pela imagem da plataforma, de Van Buren.

O discurso religioso, nas suas expressões mais cruciais e características, isto é, naquele discurso em que é comum o uso da palavra 'Deus', é um discurso que se situa nas fronteiras da linguagem, no extremo limite de nossas regras e convenções no uso das palavras (VAN BUREN, 1977, p.10).

Portanto, temos de compreender que a linguagem não é apenas um "meio" de comunicação entre os seres humanos. Ela consiste na mediação pela qual o ser humano constrói a sua "realidade" e a sua identidade, envolvendo as dimensões objetiva e subjetiva. Faz parte de nossa maneira de ser e de existir. É constitutiva do ser e por meio dela é possível projetar o "dever ser" ou o transcender. Porém, apesar de possibilitar a transcendência, a sua primeira função é organizar a imanência. Como afirma Peter Berger, 
"A linguagem usada na vida cotidiana fornece-me continuamente as necessárias objetivações e determina a ordem em que estas adquirem sentido e na qual a vida cotidiana ganha significado para mim" (BERGER, 2000, p. 38).

Podemos dizer, portanto, que o sagrado seria constituído por símbolos e signos, produzidos pelos seres humanos, que possibilitam a transcendência em função da organização da imanência. E aqui, o conceito de "realidade" assume uma profunda complexidade. Na relação com o sagrado, a fé do "ser humano religioso" é verdadeira e assume concretude a partir de seu agir.

O problema é que, segundo Buber,

O homem aspira possuir Deus; ele aspira por uma continuidade da posse de Deus no espaço e no tempo. Ele não se contenta com a inefável confirmação do sentido, ele quer vê-la difundida como um contínuo, sem interrupção espaciotemporal que lhe forneça uma segurança a sua vida, em cada ponto, em cada momento (BUBER, 1974, p.130-131).

É neste contexto que surgem a Arca da Aliança, os templos, os altares, os sacrários, as hóstias consagradas. São todas tentativas de possuir Deus, de identificar a "morada de Deus", de objetivar a presença de Deus. Esse Deus, portanto, construído historicamente nos limites das necessidades humanas, com o "barro da cultura", nós chamamos de mito. Que não se caracteriza como um "falso deus", mas como uma perspectiva objetivante do divino, que faz parte da leitura e interpretação da realidade do "homo religiosus".

\section{Extrapolando os limites do Mito e da Religião}

Diante do exposto anteriormente, a questão que levantamos aqui nos parece oportuna: seria possível a vivência da espiritualidade para além da objetivação do mito e da religião?

Chegamos então no ponto central de nossa principal hipótese: o ser humano não precisaria localizar e objetivar o mistério como sagrado, por 
meio de símbolos e signos, dependentes de uma ritualização específica de um seguimento religioso. Sendo assim, não precisaríamos colocar palavras "na boca de Deus" e nem projetar os nossos desejos como sendo os Seus. Não precisaríamos objetivar a sua imagem e nem força-lo a se manifestar sempre no mesmo lugar e da mesma forma. Assumiríamos o que pertence à nós, mantendo relação com o divino, que se manifesta e se esconde. Que habita o mistério, inacessível ao ser humano. Mas, mesmo assim, pode participar diretamente de nossa busca de plenitude, em função da busca perene da liberdade e da felicidade.

O outro é um mistério para mim. A natureza é um mistério para mim. Tudo o que me cerca se revela e se esconde ao mesmo tempo. Contudo, só "esconde" algo (mistério) porque revela algo (fenômeno). Sem a manifestação de algo o mistério não surge para o ser humano. O misterioso (o que está escondido) passa a ser consequência de algo que se revela. Nesse sentido, como podemos compreender o mistério sem antes compreender o fenômeno?

O mito é um fenômeno que nos provoca no campo da filosofia. Afinal, ele é uma forma de manifestação dos seres humanos diante do mistério. Nesse sentido, para conhecermos esse fenômeno precisamos antes conhecer os seres humanos. Como afirma Klaus Hock, referindo-se a LéviStrauss, "a melhor maneira de analisar os fundamentos do pensamento humano é por meio de mitos" (2010, p.148).

Por que os seres humanos se manifestam dessa forma? Por que em todas as culturas essa manifestação está presente? É porque algo se manifesta para ele. A consciência faz emergir a existência de algo que está escondido. Porém, não suportando a falta de explicação, de entendimento, o ser humano sente a necessidade de produzir sentido. Esse sentido não é produção racional - do ponto de vista filosófico ou científico. É um sentido que está conectado imediatamente às necessidades existenciais que representa a superação do caos. O sentido possibilita uma ordem necessária, uma "harmonia" 
construída pela necessidade, produzida pela imaginação e transformada em valores morais.

Porém, se a imaginação possibilita a transcendência dos seres humanos para além dos limites da imanência e possibilita a produção religiosa por meio de símbolos e signos que buscam uma forma de "materialização" do sagrado, a espiritualidade não precisaria, necessariamente, ser pensada nestes limites.

O mito - produzido pelos próprios seres humanos - possibilita sentido e oferece a possibilidade da cristalização de valores morais, que se transformam em normas, parâmetros, costumes, e que, por sua vez, oferece conforto e segurança diante do mistério. Mas a espiritualidade precisa "ir além". Ela precisa extrapolar estes parâmetros, estas normas, enfim, os limites do senso-comum. A espiritualidade reside no campo da ética. Isto é, sem atitude de negação, busca extrapolar os limites da moral, tomando os valores humanos como princípios que favorecem a meditação e a contemplação. Enquanto as normas morais instituídas através dos mitos e das religiões exigem aceitação passiva, os princípios exigem uma escolha livre e responsável. Enquanto as normas morais oferecem um comportamento préestabelecido por (e para) um determinado grupo social, os princípios éticos servem de referência para a reflexão e orientam o comportamento sem eximir a responsabilidade da escolha.

No campo da espiritualidade não há necessidade de superação do mistério. Ao contrário, o reconhecimento de que o mistério faz parte do "todo ordenado", do princípio ordenador do universo, possibilita ao ser humano a percepção de que ele está integrado a esse todo misterioso. Ele faz parte desse grande mistério. Portanto, nunca conseguirá possuir-se a si mesmo por completo. O que lhe resta é manter a harmonia do seu ser conectado à harmonia desse todo universal e misterioso. O grande segredo é a relação dialógica com o mistério, e não a transformação do mesmo em objeto de 
adoração. Quando objetivamos o mistério destruímos a sua essência e passamos a adorar as nossas próprias manifestações, que brotam dos nossos próprios desejos e das nossas necessidades.

Porém, esse mistério não pode ser relegado simplesmente ao campo dos sentimentos. Ele faz parte do universo racional. Ele emana desse universo. O que parece contraditório. Afinal, como posso compreender algo que não pode ser conhecido, como algo que é fruto da razão? É porque esse mistério não poderia nascer para o ser irracional. Isso pelo fato de que, a consciência, ao se tornar objeto de si mesma, pode perceber a sua infinitude e seus próprios limites no processo do conhecimento. A razão não pode atingir o que extrapola os limites do espaço e do tempo. Nesse caso o mistério não é simplesmente o desconhecido que desafia a racionalidade. É o inatingível. Porém, este não precisa ser eliminado. Ele não representa uma ameaça. Ao contrário, ele precisa ser integrado.

Um dos grandes problemas da humanidade - principalmente nos limites da cultura ocidental - é identificar o mistério como sagrado. Nesta perspectiva a tradição judaico-cristã nos força a fazer um salto injustificável e, mesmo assim, inquestionável, apesar de não possuir fundamentação.

Afinal, em que consiste o sagrado? O que define algo como sagrado?

O mistério que se refere ao que pode ser conhecido provoca o sujeito do conhecimento a adentrar no campo da filosofia para cumprir sua tarefa em busca de desvendar o desconhecido como objeto. Porém, o mistério que se refere ao que não pode ser conhecido não pode ser descartado ou abandonado pela racionalidade se revestindo da roupagem do sagrado. Ao contrário, ele precisa ser integrado de outra forma. Não como um objeto para ser adorado, nem como objeto para ser conhecido, mas como algo para ser integrado como parte da incompletude humana que transforma esse mesmo ser humano - em sua individuação - em um ser único integrado à um todo muito maior do que ele mesmo. 
Neste sentido, o místico é aquele que consegue se relacionar com o mistério sem a necessidade reduzi-lo como sagrado. Por isso, ele extrapola os limites da religião - do ponto de vista da cultura ocidental. A mística exige aceitação do mistério sem sentir-se inseguro pela falta de explicação racional. Mesmo porque, o mistério, mesmo extrapolando os limites da possibilidade do conhecer, faz parte do ser. A contemplação, por exemplo, não pressupõe a necessidade do conhecimento, mas a percepção de um mistério que faz parte da manifestação de algo que esconde uma dimensão muito maior a partir daquilo que ele revela.

\section{Conclusão}

A grande questão que nos desafia diante das provocações anteriores pode ser resumida em uma complexa pergunta: seria possível pensarmos a espiritualidade situada para além do mito e da religião institucional?

O problema que apresentamos aqui refere-se ao fato de que toda forma de objetivação do sagrado seria, por conseguinte, uma forma de institucionalização. E toda forma de institucionalização trás consigo um conjunto de valores morais que delimitam visão de mundo e comportamento de um determinado grupo social. Esta valoração que se materializa em relações interpessoais se mantém culturalmente por meio de símbolos e signos. Contudo, o que não podemos ignorar é que, no campo do mito e da religião, este conjunto de significados constitui uma forma de ideação construída a partir de narrativas simbólicas que acionam a imaginação. Portanto, se levarmos em conta que as narrativas que mais influenciaram e influenciam a nossa cultura foram as construídas pelo colonizador, então as imagens que "entraram em ação" influenciando a nossa visão de mundo, foram construídas pelo "vencedor" e dominador. O que nos revela a importância do mito e da religião no processo de colonização da 
subjetividade, tendo em vista a construção de uma dominação concreta e objetiva.

Portanto, no campo da moral religiosa podemos perceber facilmente a cristalização de valores machistas, racistas e autoritários. É por isso que, em nossa cultura Deus carrega a imagem do masculino, tendo de ser chamado e identificado como Pai; o sagrado carrega a "roupagem" do branco, enquanto o negro é diabolizado.

Compreendemos que somente no campo da ética poderemos extrapolar os limites do mito e da religião institucionalizada, constituídos a partir das narrativas colonialistas. Entendemos que somente no campo da ética seria possível a vivência da mística e da espiritualidade libertadora.

Para além dos limites da cultura fundamentada no senso comum.

\section{Referências}

AMORIN, Sérgio Gonçalves de. A Imaginação Simbólica e as Hierofanias Reequilibrantes na Modernidade: Presenças Femininas no Campo Religioso Contemporâneo Ocidental. Goiânia, XI Simpósio Nacional da Associação Brasileira de História das Religiões, 2009.

BEAUFRET, Jean. Introdução às Filosofias Existencialistas: de Kierkegaard a Heidegger. Trad. Salma Tannus Muchail, São Paulo: Ed. Duas Cidades, 1976. BERGER, Peter L. \& LUCKMANN, Thomas. A Construção Social da Realidade. Tradado de Sociologia do Conhecimento. 34를 ed. Petrópolis: Ed. Vozes, 2012.

BERGER, Peter L. O Dossel Sagrado: Elementos para uma Teoria Sociológica da Religião. São Paulo: Ed. Paulus, 1985.

BUREN, Paul Van. Alle Frontiere del Linguaggio. s.l.: Armando editore, 1977. Ed. Original: The Edges of Linguage; an Essay in the Logico of Religion. New York, NY: The Macmillan Company, 1972.

BUBER, Martin. Eu e Tu. São Paulo: 2ª ed. Ed. Moraes, 1978. (Introdução e Tradução: Newton Aquiles Von Zuben).

BULHOF, Ilsen; KATE, Laurens. Flight of the Gades: Philosophical Perspectives on Negative Theology, New York, Fordaham Univertity Press, 2000.

CASSIRER, Ernest. Linguagem e Mito. São Paulo: Ed. Perspectiva, 1997. . O Mito do Estado. Rio de Janeiro: Ed. Zahar, 1976. (Trad. Álvaro Cabral) 
CROATTO, José Severino. As Linguagens da Experiência Religiosa: Uma Introdução à Fenomenologia da Religião. 3ae ed., São Paulo: Ed. Paulinas, 2010.

DERRIDA, J. Fé e Saber. As duas fontes da "religião" nos limites da simples razão. In. VV.AA. A Religião. São Paulo: Ed. Estação Liberdade Ltda. 2000.

DUARTE, Newton. Sociedade do Conhecimento ou Sociedade das Ilusões? Polêmicas do Nosso Tempo. Campinas: Ed. Autores Associados, 2003.

DURAND, Gilberto. As Estruturas Antropológicas do Imaginário - Introdução à Arqueologia Geral. São Paulo: Ed. Martins Fontes, 2002. (Trad. Hélder Godinho)

. A imaginação simbólica. Lisboa: Arcádia, $1979 b$.

O Imaginário: ensaio acerca da ciência e da filosofia da imagem. $4^{\mathrm{o}} \mathrm{Ed}$, DIFEL, Rio de Janeiro, 2010

DURKHEIM, Émile. As Formas Elementares de Vida Religiosa. 3aㅗ ed. São Paulo: Ed. Paulus, 2008. (Trad. Joaquim Pereira Neto)

FEUERBACH, Ludwig. A Essência do Cristianismo. 2a ed. Campinas: Ed. Papirus, 1997 (Trad. José da Silva Brandão)

GEERTZ, Clifford. A Interpretação das Culturas. Rio de Janeiro: Ed. LTC, 2008. GIRARD, René. A Violência e o Sagrado, São Paulo: Ed. UNESP \& Paz e Terra, 1990. (Trad. Martha Conceição Gambini).

HEIDEGGER, Martin. A caminho da linguagem. Petrópolis: Vozes, 2003 Kant e o Problema da Metafísica, México: Ed. Fundo de Cultura Econômica, 1986, p.217.

. Ser e Tempo, parte II. Rio de Janeiro: Editora Vozes, 1989. (Trad.

Márcia de Sá Cavalcanti)

HOCK, Klaus. Introdução à Ciência da Religião, São Paulo: Ed. Loyola, 2010.

HUSSERL, Edmund. A Crise da Humanidade Europeia e a filosofia. Introdução e Tradução de Urbano Zilles. Porto Alegre: Ed. Edpucrs, 1996. (Col. Filosofia, n.41)

KIERKEGAARD, S. Temor e Tremor. Tradução de Maria José Marinho, Introdução de Alberto Ferreira. Lisboa: Guimarães Editores, 1990.

MERLEAU-PONTY, Maurice. (1994). Fenomenologia da percepção (C. Moura, Trad.). São Paulo: Ed. Martins Fontes, 2006. (Texto original publicado em 1945)

NOVASKI, Augusto. Mito e Racionalidade Filosófica. In. Regis de Morais. As Razões do Mito. Campinas: Ed. Papirus, 1988.

PAINE, Scott Randall. Filosofia da Religiao. In. PASSOS, João Décio \& USARSKI, Frank. Compêndio de Ciências da Religião. São Paulo: Ed. Paulinas / Paulus, 2013.

PERINE, Marcelo. Ensaio de Iniciação ao Filosofar. São Paulo: Ed. Loyola, 2007. SANTA CLARA, Nilton da Silva. Enrique Dussel - Filosofia, Teologia e Libertação. São Paulo: Ed. Fonte Editorial, 2014.

TILLICH, Paul. Teologia Sistemática. 2ª ed. São Paulo: Ed. Paulinas, 1987. 
VAN BUREN, Paul M. Asse Fronteire dês Linguaggio. Roma: Armando Editora, 1977.

ZILLES, Urbano. O problema do conhecimento de Deus. $2^{\text {a }}$ ed. Porto Alegre: Ed. EDIPUCRS, 1989. (Col. Filosofia, no 61 ). 